International Journal of Automotive and Mechanical Engineering ISSN: 2229-8649 (Print); ISSN: 2180-1606 (Online)

Volume 15, Issue 1 pp. 4962-4977 March 2018

(C) Universiti Malaysia Pahang, Malaysia

DOI: https://doi.org/10.15282/ijame.15.1.2018.6.0385

\title{
Performance Enhancement of Internal Combustion Engine Using Weight Reduction Approach
}

\author{
H. J. Parekh ${ }^{1^{*}}$, B. M. Ramani ${ }^{2}$ and C. J. Parekh ${ }^{3}$ \\ ${ }^{1}$ Gujarat Technological University, Ahmedabad, Gujarat, India \\ *Email: hemang2411@ rediffmail.com \\ Phone: 09426481731 \\ ${ }^{2}$ SLTIET, Rajkot, Gujarat Technological University, Ahmedabad, Gujarat, India \\ ${ }^{3}$ MEFGI, Rajkot, Gujarat Technological University, Ahmedabad, Gujarat, India
}

\begin{abstract}
The purpose of this study is to investigate and enhance the performance of the single cylinder 4- stroke water cooled diesel engine using weight reduction approach. Initially, the existing engine of $3.7 \mathrm{~kW}(5 \mathrm{hp})$ was tested for performance analysis as per the method mentioned in IS 11170 for loop test by altering its speed then an engine was critically studied for weight reduction possibilities and modified accordingly. The modified engine has been tested again following the similar method. The various performance and emission parameters of both the engines at their most suitable speed were measured and compared. From the result, it was concluded that the modified engine shows better result from performance and emission aspects along with better mobility and convenience at a reduced cost. However, the modified engine needs strong base plate as a foundation because of little higher speed.
\end{abstract}

Keywords: Four-stroke diesel engine; weight reduction; performance analysis; emission aspects

\section{INTRODUCTION}

Owing to their excellent drivability and fuel economy, diesel engines are the most common internal combustion engines that are widely used in various sectors such as agriculture, transportation, and industry. Rajkot is one of the leading center and hub for manufacturing and assembling of various automobile parts and all types of diesel engines which are used for various applications in the field of irrigation, small capacity generator set and agriculture.

Referring to the results of a recent survey conducted, there will be a phenomenal rise in energy consumption in coming years which will worsen the energy scenario and increase the importance of performance and emission aspects [1-3]. Therefore, the engine manufactured by local manufacturers for agriculture are to be tested as per IS:11170:1985, i.e. Indian standard for performance aspects of diesel engine used in the agriculture field with rated brake power less than $19 \mathrm{~kW}$.

However, this standard is not covering any requirements related to emission aspects. Considering performance and emission as key criteria for survival, this industry is facing strong competition in the international market. Therefore, it is decided to study and investigate this issue by conducting an experimental analysis of selected engine from performance and emission aspects. It is also felt that as the selected engine is specifically used in the field of agriculture it should be light in weight for better 
mobility and convenience, therefore weight reduction possibilities have been investigated. This paper presents a detailed study which covers performance and emission improvement of the single cylinder four stroke water cooled engine following weight reduction approach. Results obtained were also compared.

Performance and emission enhancement in the diesel engine is not a new concept. Lot of work has been done in this aspect of a diesel engine. The various authors have studied and suggested different methods for achieving this objective. In diesel engines, significant research efforts $[4,5]$ have been conducted in direction of using various blends of biodiesel as fuels. It might be because of the fact that the fuel characteristics of biodiesel are approximately the same as those of fossil diesel fuel and thus it can be used directly in the engine without any major modification. [6, 7].

Considerable reductions in the emission of various emission elements like CO, $\mathrm{SO}_{\mathrm{X}}$ smoke, and particulate matter are observed while using various type of biodiesel in a diesel engine as a fuel [8, 9]. Jaichandar and Annamalai [10] conducted the experiment on single cylinder four stroke constant speed engine at different loading condition using methyl ester biodiesel as a fuel. It was observed that although there was a slight increase in BSFC and a corresponding decrease in thermal efficiency, the considerable reduction in emission parameters like CO, HC, and smoke. Neyda et al. [11] worked on a study of various biodiesel proprieties and indicated that among the different vegetable oils jetropha curcas oil has some good characteristics, such as higher cetane number, less dense, higher oxygen content, lower acidity, better oxidation stability and suitability for storage. Dubey and Gupta [12] performed the experiment to identify the performance of a combination of Jetropha biodiesel and turpentine oil in diesel engine under different loading conditions, this combination found superior from the emission point of view as at full load condition, considerable emission reduction of $\mathrm{CO}, \mathrm{NO}_{\mathrm{X}}$, and $\mathrm{CO}_{2}$ was observed. Azad et al. [13] evaluated performance and emission characteristics of multi-cylinder diesel engine with soybean and waste oil biodiesel fuels. The results indicated that thermal performance of the engine decreases slightly with an increase in biodiesel blend; however, emission decrease with increase in biodiesel blends. Further, it was observed that waste oil biodiesel showed a better trend of emission reduction as compared to soybean biodiesel.

Several studies have evaluated the effect of injection timing, pressure, and duration on performance and emission of biodiesel blended diesel engine [14-18]. Liang et al. [19] identified the impact of the various factors like pressure, timing and duration of combustion on the performance of the engine. On the basis of the results, he concluded that higher combustion pressure, longer duration of combustion and advancement in timing was desirable for the better engine performance however the author took the biodiesel as a fuel, but the same results are applicable to the engine running on conventional diesel. Rostami et al. [20] studied the effect of fuel injection timing on engine performance at different speed. The results indicated that advancement in injection timing led to decrease in the BSFC and exhaust temperature, which lead to increase in the performance. Sathiyamoorthi and Sankaranarayanan [21] investigated the effect of advancement in injection timing on performance and emission of direct injection diesel engine fueled with different blends of lemongrass oil and observed that optimal injection timing for that engine was $27^{\circ}$ BTDC as a noticeable gain in performance and improvement in emission was obtained with this timings.

However, it was observed that using biodiesel as fuel in existing engine resulted in slight power loss, lower thermal efficiency and higher emission of nitrogen oxides [22-24] This might have happened because of the fact that the formation of $\mathrm{NO}_{\mathrm{X}}$ is 
highly dependent on in-cylinder temperature, the oxygen concentration and residence time for the reaction to take place [25]. Detailed study of a literature review [26] emphasized that most responsible factor for $\mathrm{CO}$ emission is the absence of excess oxygen in fuel. Some other important factors which are responsible for the $\mathrm{CO}$ emission are air/fuel ratio, injection timing, engine speed, injection pressure and fuel characteristics [27]. In this connection, Chauhan et al. [28] studied the effect of loading condition on $\mathrm{NO}_{\mathrm{X}}$ and $\mathrm{CO}$ emission. There was an increase in $\mathrm{NO}_{\mathrm{X}}$ emission linearly with the load because of higher combustion temperature at higher load which is considered as a most important factor for the emission of $\mathrm{NO}_{\mathrm{X}}$. This study also found that at higher load the amount of air remains same, but fuel quantity increased which resulted in higher $\mathrm{CO}$ emission, therefore, $\mathrm{CO}$ emission also increase linearly with the load. However, Abdelrahman [29] in his research mentioned that in a diesel engine, rich mixture exists locally even if excess air is present in the combustion chamber and combustion may be poor due to a lower temperature at no load condition which might be the reason of higher $\mathrm{CO}$ emission at no load condition.

İçıngür and Altiparmak [30] evaluated the effect of fuel cetane no and injection pressure on diesel engine performance and emission. They mentioned that engine torque and power at maximum torque speed were increased by 5 and $4 \%$ respectively with increasing cetane no of 46 to 54.5. However further increase was not resulted in significant change in performance. $\mathrm{NO}_{\mathrm{X}}$ emission was reduced by $10 \%$ with an ncrease in cetane no from 46 to 61 . Semin et al. [31] investigated the effect of fuel injection pressure (FIP) on performance and fuel consumption of diesel engine at fixed load with various speeds. The experimental results obtained showed that, increasing the fuel injection pressure resulted in a higher value of IHP and BHP at higher speed. However, the value of SFC decreased with increase in the FIP from 180 bars to 200 bar only when the speed of the engine was higher than $1000 \mathrm{rpm}$. Some studies mentioned [32, 33] that higher FIP improve fuel air mixing which resulted in faster combustion that directly influences the emission aspects. Zhang et al. [34] observed that increase in FIP leads to improved air-fuel mixture formation which ultimately reduces smoke and $\mathrm{CO}$ emission. Radha et al.[35] analyzed the effect of varying injection pressure and injection timing simultaneously on four stroke, single cylinder, constant speed, water cooled diesel engine fueled with three different vegetable oils. It was observed that the performance of jojoba methyl ester found superior for higher injection pressure with minimum emission. Agarwal et al. [36] observed the effect of fuel injection on emission and performance of single cylinder diesel engine and they achieved the improvement in performance and emission by lowering the FIP at higher speed.

Modifications in compression ratio, EGR, injection process and parameters [37] have a significant impact on engine power, efficiency and exhaust emissions. Shahadet et al. [38] examined the combined effect of EGR and inlet air preheating on engine performance and concluded that at medium load condition $\mathrm{NO}_{\mathrm{X}}$ and $\mathrm{CO}$ emission along with BSFC decreased when inlet air preheating and EGR were applied together. Ravikumar et al. [39] analyzed the effect of compression ratio and EGR on performance, combustion, and emission of a diesel engine. The test was conducted at different compression ratios with different loads and for different EGR rates. The results indicated that the increase in compression ratio resulted in higher brake thermal efficiency. Increase in the brake thermal efficiency by $13.5 \%$ and reduction in $\mathrm{NO}_{\mathrm{X}}$ emission by $11 \%$ was observed with increase in EGR percentage. Laguitton et al. [40] examined the effect of $\mathrm{CR}$ on the emission of diesel engine The results of a study 
indicated that, although there was a small $\mathrm{CO}$ and $\mathrm{HC}$ penalty, either reducing the $\mathrm{CR}$ or decreasing the IT greatly reduced $\mathrm{OP}$ and $\mathrm{NO}_{\mathrm{X}}$ emission.

Canakci et al. [41] analyzed the effect of speed on various engine parameters and claimed that speed is one of the important parameters for improvement in performance and emission aspect because it positively affects the turbulence level of air entering into the cylinder, volumetric efficiency and engine friction. Baker and Lee [42] observed that at a lower speed, the reactive gas provides a longer time for the nitric oxide to form and this resulted in higher nitric oxide concentration in the combustion chamber which resulted in higher nitric oxide emission. However nitric oxide emission was decreased with the increase of engine speed. Jindal [43] investigated the effects of the engine operating parameters like compression ratio, fuel injection pressure, injection timing and engine speed on the emission of $\mathrm{NO}_{\mathrm{X}}$ and found that higher compression ratio, injection pressure, and speed resulted in the lower emission of $\mathrm{NO}_{\mathrm{X}}$ for pure diesel as well as diesel blended with biodiesel. Sayin et al. [44] indicated that increase in speed could probably augment volumetric efficiency, boosting turbulence in combustion chamber hence ensure better combustion which ultimately resulted in to lower $\mathrm{CO}$ emission at a higher speed so considering this fact higher speed is desirable for lower $\mathrm{CO}$ emission.

It can be observed from literature that many studies have presented variation in design factors like; alteration of fuel, use of various blends with biodiesel, variation of compression ratio, fuel injection pressure, fuel Injection timing for improvement in performance and emission parameters while other studies have presented variation in operating parameters like cetane no, load, speed and weight of the engine. To achieve performance enhancement and emission improvement along with better mobility and convenience, one of the prominent methods is weight reduction approach with a corresponding increase in the speed which has been applied in the present investigation. The effect of higher speed has already been discussed in this literature review.

\section{APPLICATION OF WEIGHT REDUCTION APPROACH IN FLYWHEEL}

After carrying out the critical study of drawings of various parts of the engine the flywheel was selected for application of weight reduction approach. The different patterns of flywheel available with the manufacturer were studied and the proper flywheel was selected. The diagram of flywheel showing the various critical dimensions is shown in Figure 1. The detailed technical specifications of existing and modified flywheels are shown in Table 1.

From the diagram and specification table, it can be observed that for reducing the weight of flywheel the material is removed from the web thickness ( $t 1)$ and rim width (W) such that the moment of inertia remained undisturbed. To compensate the said reduction, the thickness of the rim (t) is increased. Ultimately, the weight of the modified flywheel has been reduced to 9 from $18 \mathrm{~kg}$. After adopting these changes modified engine is developed. 


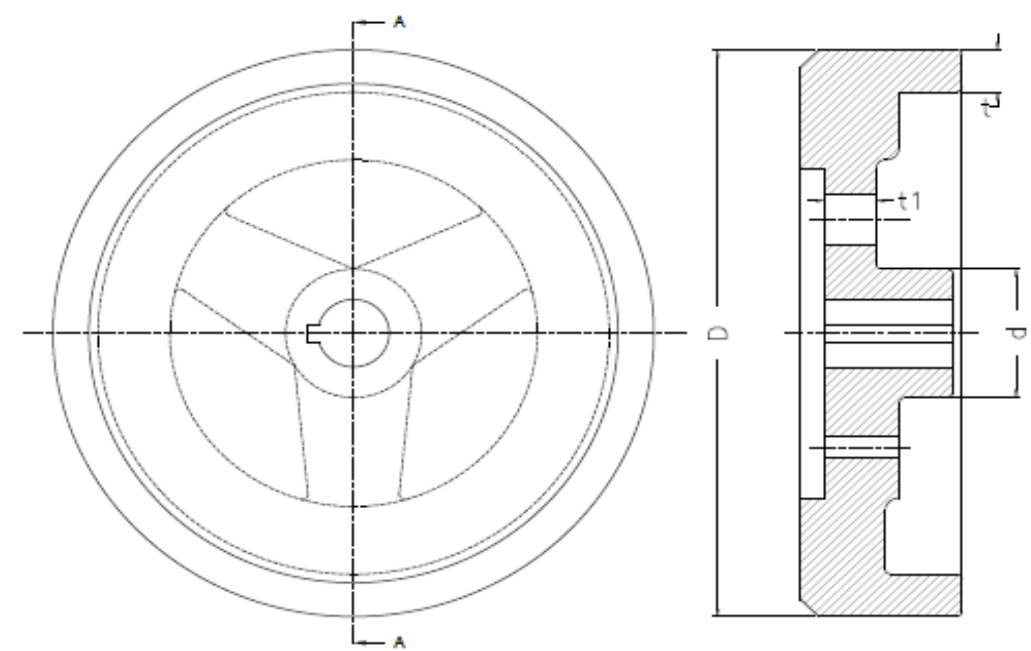

Figure 1. Flywheel

Table 1. Specifications of the flywheel.

\begin{tabular}{lcc}
\hline Dimensions & Existing flywheel & Modified flywheel \\
\hline Weight & $18 \mathrm{~kg}$ & $9 \mathrm{~kg}$ \\
O.D. (D) & $287 \mathrm{~mm}$ & $280 \mathrm{~mm}$ \\
Rim thickness (t) & $25 \mathrm{~mm}$ & $35 \mathrm{~mm}$ \\
Web thickness (t1) & $25 \mathrm{~mm}$ & $20 \mathrm{~mm}$ \\
Rim width (W) & $70 \mathrm{~mm}$ & $30 \mathrm{~mm}$ \\
\hline
\end{tabular}

\section{DEVELOPMENT OF MODIFIED ENGINE}

It was expected that the modified engine with lighter flywheel needs to operate at a higher speed to maintain the same rated power. For enabling the engine to run at higher speed the following additional modifications were done in the engine.

a) Reduction of bore diameter from 85 to $76 \mathrm{~mm}$.

b) Reduction in stroke length from 80 to $78 \mathrm{~mm}$.

c) Change in the crank diameter at flywheel end from 40 to $35 \mathrm{~mm}$ as per the pattern of the modified flywheel.

\section{EXPERIMENTAL SETUP}

\section{Design of Experiment and Testing Parameters}

Figure 2 shows a schematic representation of diesel engine testing facility used in the present investigations. A single cylinder vertical water cooled naturally aspirated 4stroke constant speed DI engine of VIJAY brand model VIC-1 having compression ratio 16.5:1 and Indian Standard (IS) rating of $3.7 \mathrm{~kW}$ at $1800 \mathrm{rpm}$ was selected for the study which is widely used in agriculture for energy applications. The detailed specifications of the existing and modified engines are shown in Table 2. The arrangement for carrying out performance and emission test simultaneously was done. 
The engine was coupled to a hydraulic dynamometer with a coupler to control engine speed and load. The digital control panel having an arrangement for measurement of applied load, speed and fuel consumption digitally was attached to the hydraulic dynamometer. The inlet and outlet temperature of cooling water were measured by thermometers which are attached to corresponding passages. Digital exhaust gas pyrometer and Testo-350 exhaust gas analyzer were connected to the exhaust for measurement of exhaust gas temperature and major pollutants like $\mathrm{CO}$ and $\mathrm{NO}_{\mathrm{X}}$. Parameters observed for performance and emission analysis were power produced by the engine, engine speed (rpm), fuel consumption characteristics, exhaust temperature, $\mathrm{CO}$ and $\mathrm{NO}_{\mathrm{X}}$ at different loading conditions.

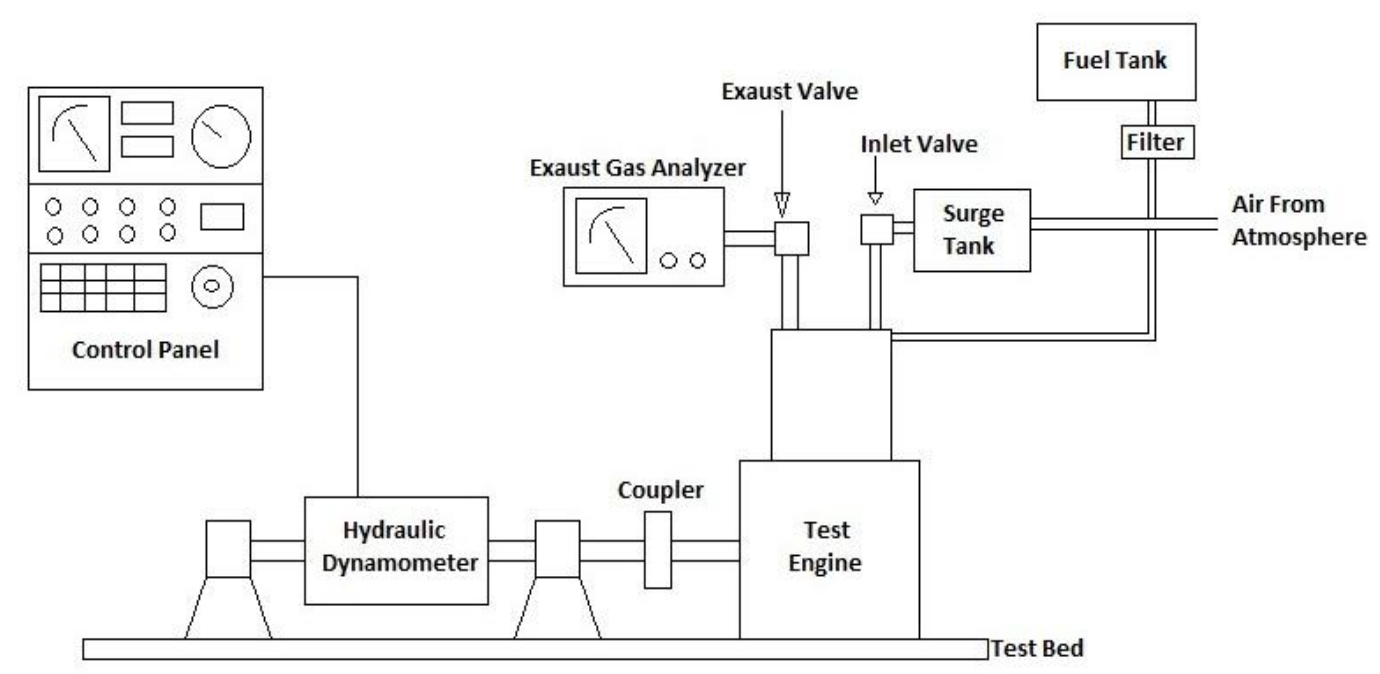

Figure 2. Schematic diagram of testing setup.

\section{Experimental Procedure}

The engine was started and after achieving steady state conditions it was loaded gradually to keep the speed within the permissible range. As per the methods mentioned in IS:11170 the loop test was conducted on both engines in which there is an increment of the load by $20 \%$ after every half hour started ranging from no load to full load and final reading is taken at $10 \%$ overload condition. To maintain the constant speed during the experiment while the changing load, the quantity of diesel injected was varied by speed governor. After completing the experiment at a selected speed, the speed of the engine can be altered by loosening or tightening the governor spring. Observations in respect of performance characteristics were taken at a different speed ranging from 1500 to $2200 \mathrm{rpm}$ for existing engine and from 2000 to $2600 \mathrm{rpm}$ for a modified engine. Results were studied for determination of the most suitable speed for each engine. The emission test was carried out on both the engines at their most suitable speed for measurement of various pollutants like $\mathrm{CO}$ and $\mathrm{NO}_{\mathrm{X}}$ for verifying emission aspects. The results obtained by gas analyzer were validated at the independent laboratory by conducting stack analysis method at the full load. 
Table 2. Specification of 4- stroke single cylinder water cooled engine.

\begin{tabular}{lcc}
\hline Description & Existing engine & Modified engine \\
\hline Rated Power $(\mathrm{kW})$ & 3.7 & 3.7 \\
Speed variation $(\mathrm{rpm})$ & $1500,1800,2000 \& 2200$ & $2000,2200,2400 \& 2600$ \\
Bore $(\mathrm{mm})$ & 85 & 76 \\
Stroke $(\mathrm{mm})$ & 80 & 78 \\
Mechanical efficiency $(\%)$ & 80 & 80 \\
(Taken from IS standard) & & \\
Altitude (m) & $140 \mathrm{~m}$ & $140 \mathrm{~m}$ \\
Nominal compression ratio & $16.5: 1$ & $16.5: 1$ \\
Specific gravity of fuel & 0.83 & 0.83 \\
Calorific value (kJ/kg) & 43,900 & 43,900 \\
Oil specification & Yantrol-32 & Yantrol-32 \\
Cooling & water & water \\
\hline
\end{tabular}

\section{RESULTS AND DISCUSSION}

\section{Fuel Consumption}

Fuel consumption gives the amount fuel consumed per hour to develop the rated power and it generally increased linearly with an increase in the percentage of load. The fuel consumption of existing engine was measured at four different speeds i.e. 1500, 1800, 2000 and $2200 \mathrm{rpm}$ and for the modified engine, it was measured at four different speeds i.e. 2000, 2200, 2400 and $2600 \mathrm{rpm}$ with different load condition varying from no load to overloading condition. It was observed that the existing engine gives lowest fuel consumption in entire range at $1800 \mathrm{rpm}$ (Figure 3) while the modified engine gives the lowest fuel consumption ranging from no load to an overload condition at $2600 \mathrm{rpm}$. (Figure 4).

\section{Brake Specific Fuel Consumption}

Brake specific fuel consumption is the most important parameter of an engine and is defined as the consumption per unit of a power in a time unit. While measuring the brake specific fuel consumption it was observed that brake specific fuel consumption decreased in all experimental conditions with an increase in engine load, however, it again increased slightly for overloading condition.

This reduction might be the result of continuous improvement in combustion quality and efficiency with increased load. Cylinder pressure increases with higher load resulted in increased injected fuel quantity, which burned more efficiently reducing brake specific fuel consumption at higher load. Further, the results obtained from the experiment concluded that the lowest BSFC for existing engine for entire loading condition was observed at $1800 \mathrm{rpm}$ (Figure 5), and for the modified engine, it was observed at $2600 \mathrm{rpm}$ (Figure 6). 


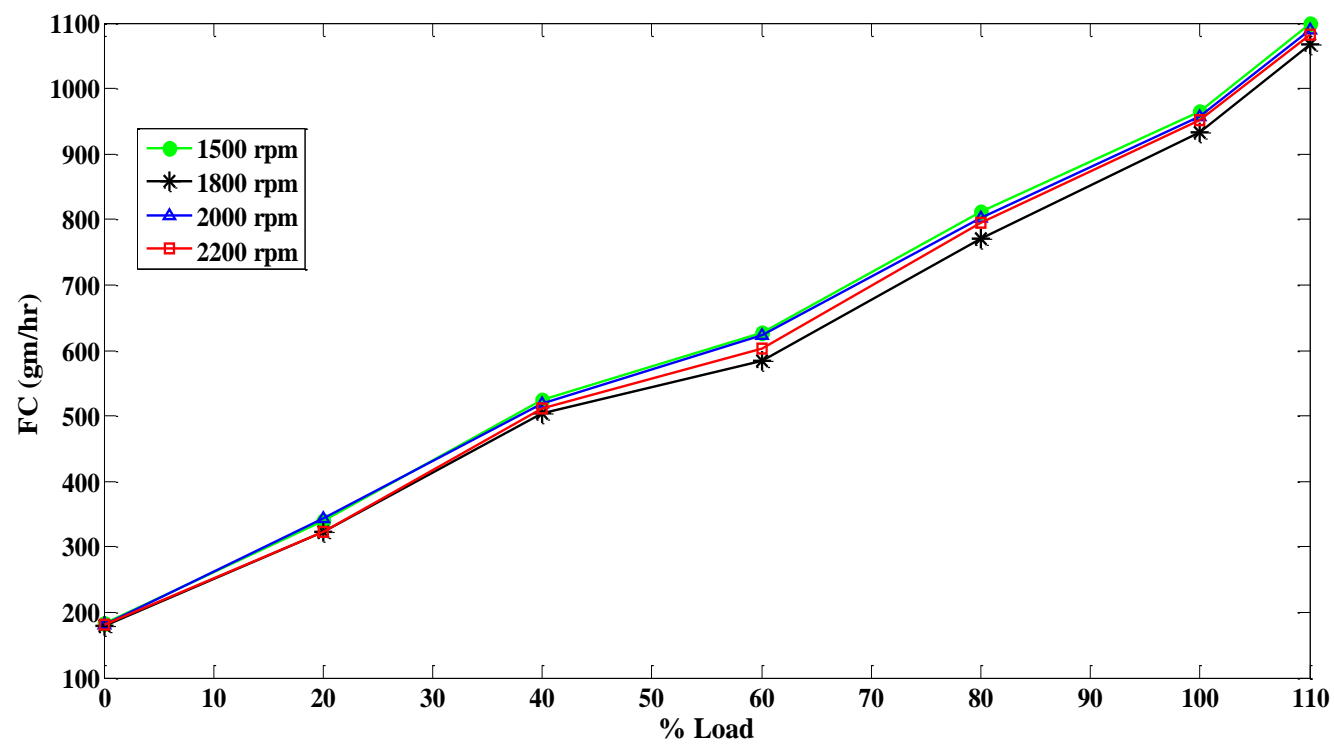

Figure 3. Fuel consumption of the existing engine.

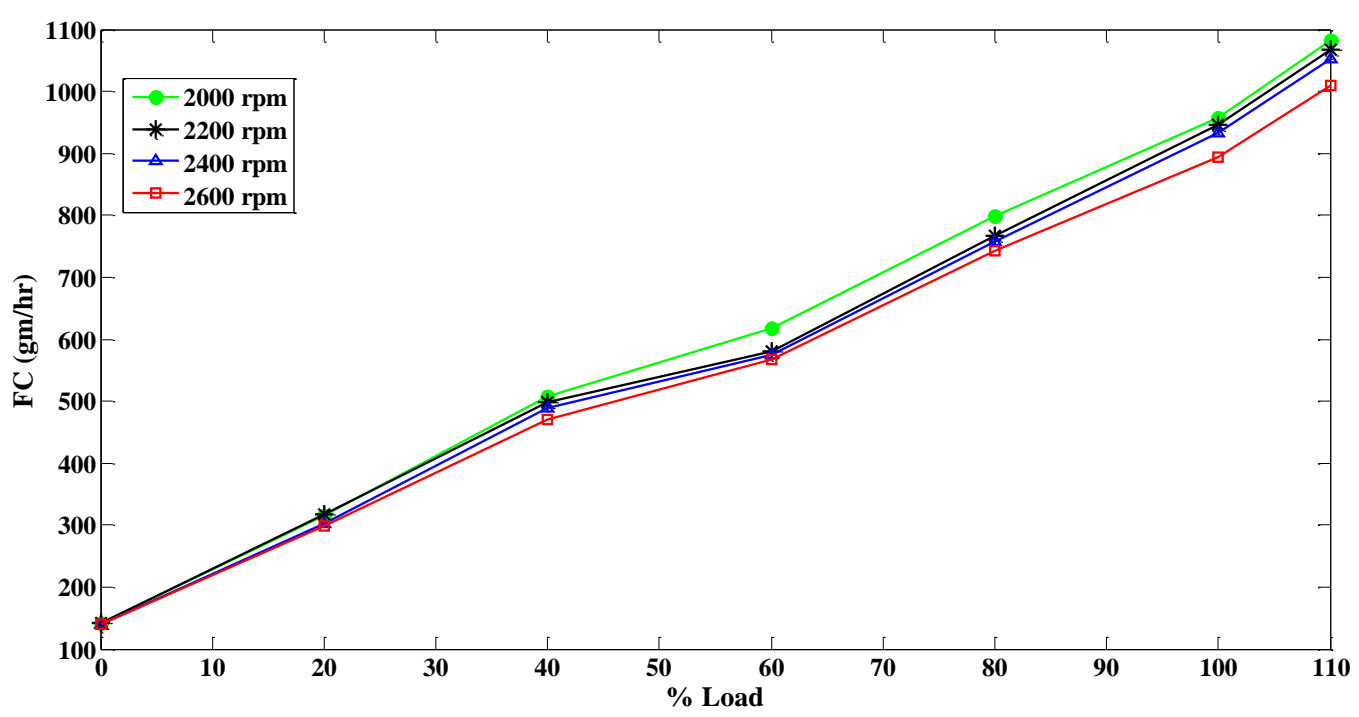

Figure 4. Fuel consumption of the modified engine. 


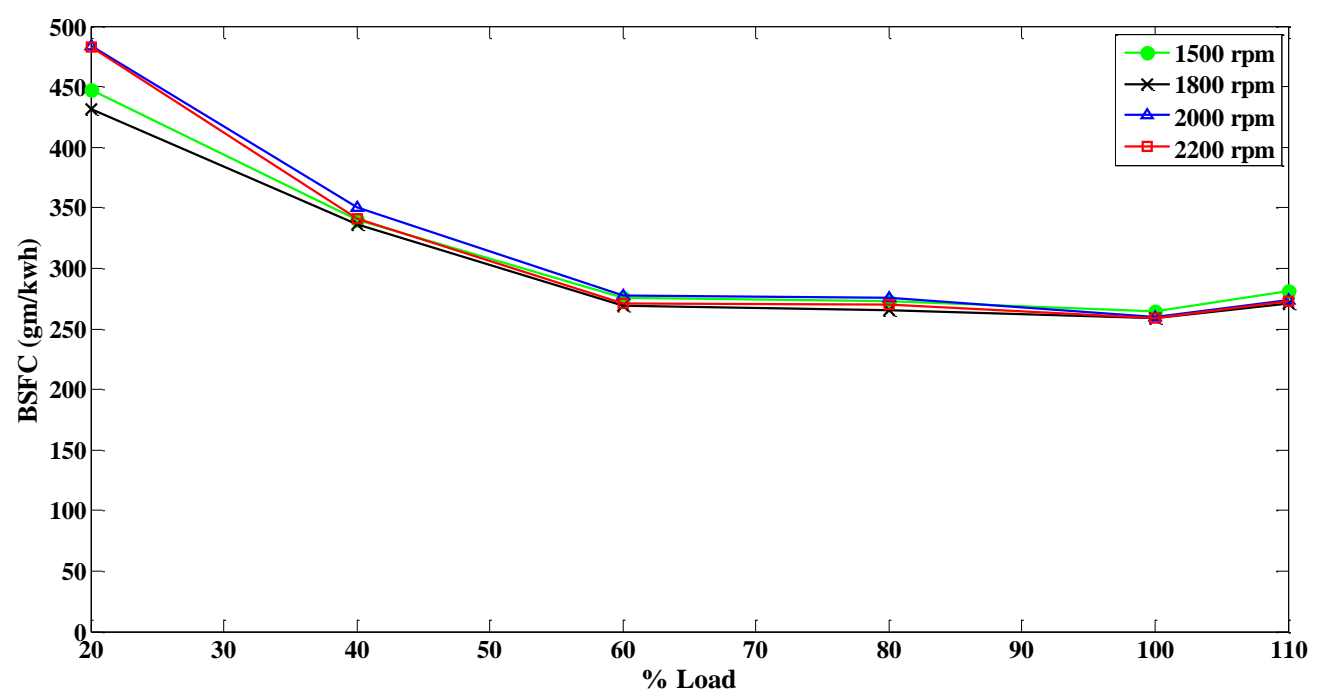

Figure 5. Brake specific fuel consumption of existing engine.

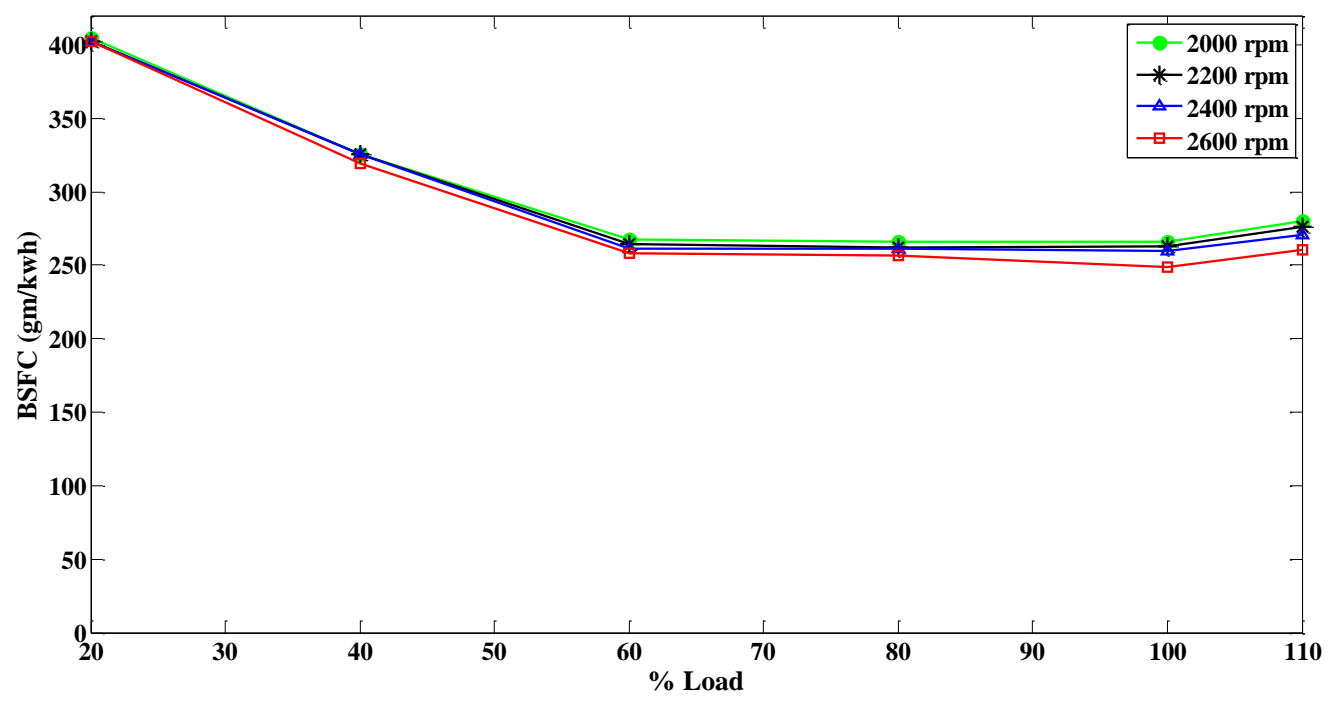

Figure 6. Brake specific fuel consumption of the modified engine.

\section{Brake Thermal Efficiency}

Brake thermal efficiency is the ratio of the output or work done by a substance in a cylinder at a given time to the input or heat energy of fuel supplied during the same time. It was observed from the results that thermal efficiency increased with the increase in the load up to full load condition which indicated that larger portion of combustion heat has been converted into work with an increase in the load. However, under overloading condition, the thermal efficiency decreased slightly because of incomplete combustion of fuel. It was also observed that the highest thermal efficiency was achieved in existing engine at $1800 \mathrm{rpm}$ (Figure 7) and for the modified engine, it was achieved at $2600 \mathrm{rpm}$ (Figure 8). 


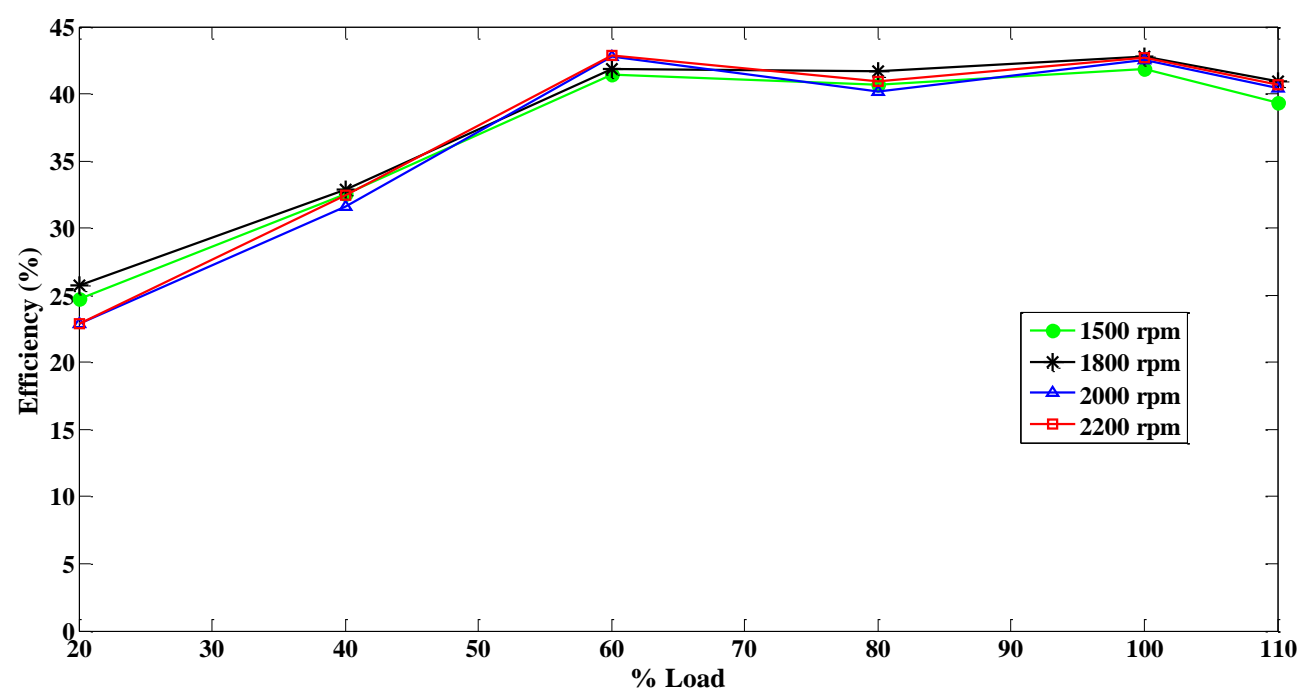

Figure 7. Brake thermal efficiency of the existing engine

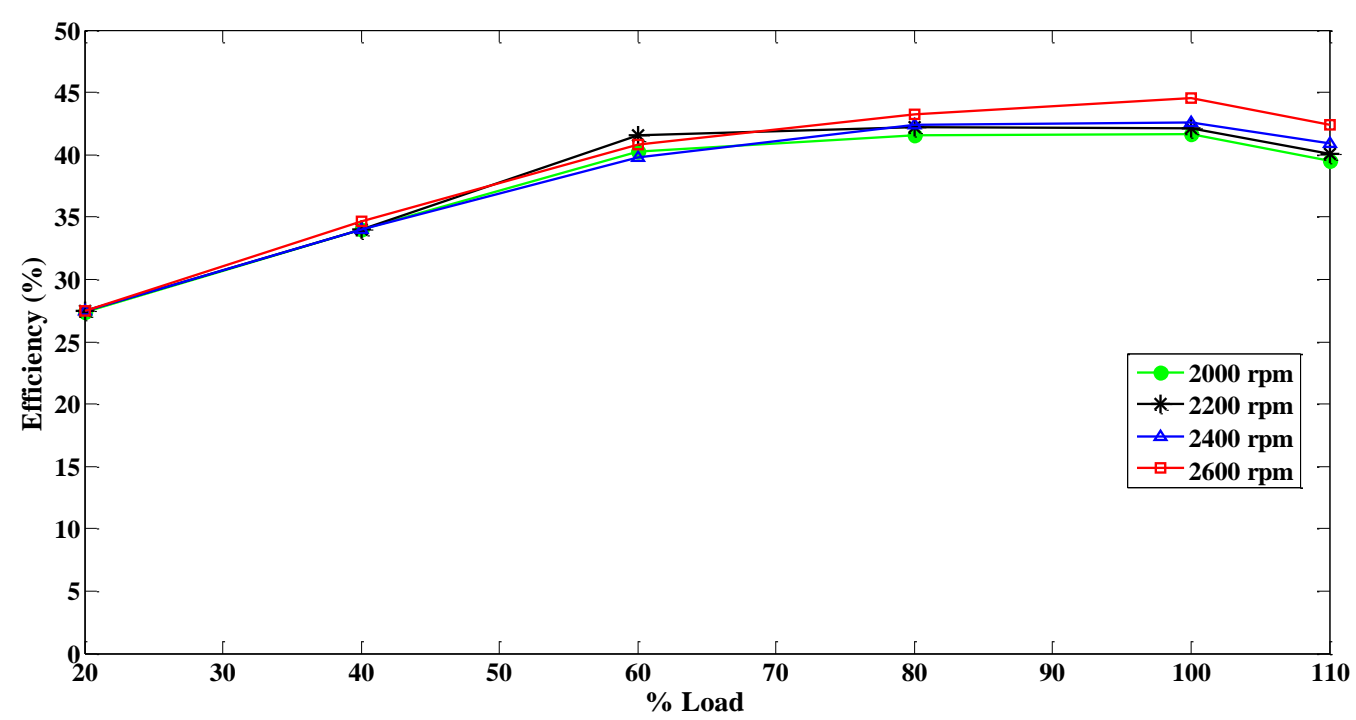

Figure 8. Brake thermal efficiency of the modified engine

\section{Comparative Analysis of Thermal Efficiency}

For conducting a comparative analysis of performance, it is desirable to find out the most suitable speed for each engine. The best values of performance parameters were achieved in existing engine at $1800 \mathrm{rpm}$ and for the modified engine at $2600 \mathrm{rpm}$, therefore the most suitable speed for the existing engine and modified engine are 1800 $\mathrm{rpm}$ and $2600 \mathrm{rpm}$ respectively. While comparing the thermal efficiency of both engines at different load condition at their most suitable speed it was observed that at almost all point from no load to overload condition the modified engine produced better thermal efficiency by approximately $2 \%$ as compared to an existing engine (Figure 9). This performance enhancement is achieved by reducing the weight of the flywheel and corresponding increase in the speed. Higher speed probably increases volumetric 
efficiency, boosting turbulence in combustion chamber hence ensure better combustion which might have resulted in higher thermal efficiency in a modified engine.

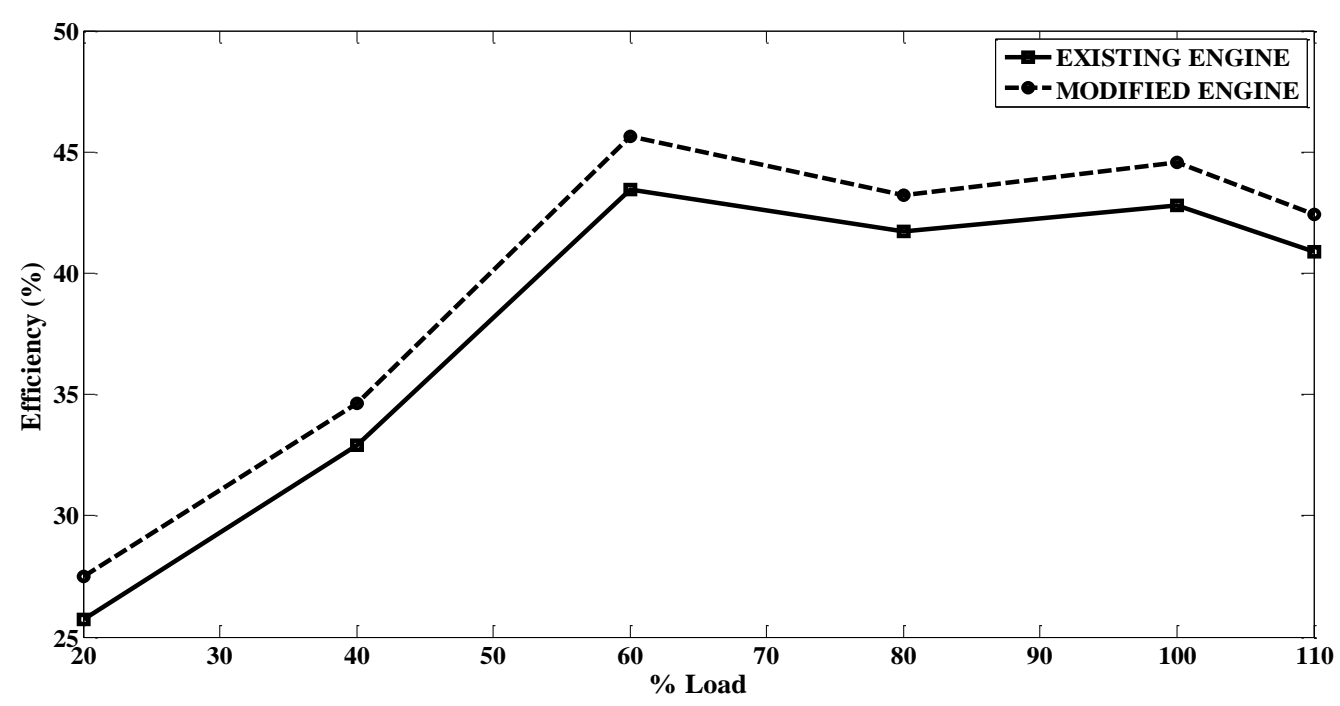

Figure 9. Thermal efficiency comparison at different loading conditions.

\section{CO Emission}

Considering the toxic nature of $\mathrm{CO}$, it must be controlled. It is an intermediate product in the combustion of a hydrocarbon fuel produced due to incomplete combustion. Emission of $\mathrm{CO}$ depends on the air-fuel ratio relative to the stoichiometric proportion. The comparative analysis of $\mathrm{CO}$ emission at different loading condition is shown in Figure10. Higher CO Emission was observed with increase in load because higher load resulted in more amount of diesel fuel injected into the combustion chamber. As the amount of air remains same and fuel quantity increased, the occurrence of incomplete combustion might have resulted in higher $\mathrm{CO}$ emission.

It was observed that the $\mathrm{CO}$ emission of the modified engine was lower than existing engine in entire loading range from no load to full load. This might be due to the higher speed of the modified engine that could have probably augment volumetric efficiency, boosting turbulence in combustion chamber hence ensure better combustion which resulted into lower $\mathrm{CO}$ emission by approximately $4 \%$ in the modified engine at all loading condition.

\section{NO $_{\mathrm{X}}$ Emission}

The most trouble emissions from $\mathrm{CI}$ engines are $\mathrm{NO}_{\mathrm{X}}$ which contains nitric oxide (NO) and nitrogen dioxide $\left(\mathrm{NO}_{2}\right)$. The combustion temperature inside the engine cylinder and the local stoichiometric mixture are the most important factors for the formation of $\mathrm{NO}_{\mathrm{X}}$. The variation of $\mathrm{NO}_{\mathrm{X}}$ emission for both engines at different load conditions is shown in Figure11. It can be observed that the $\mathrm{NO}_{\mathrm{X}}$ emissions increased with the engine load because of higher combustion temperature at higher load. 


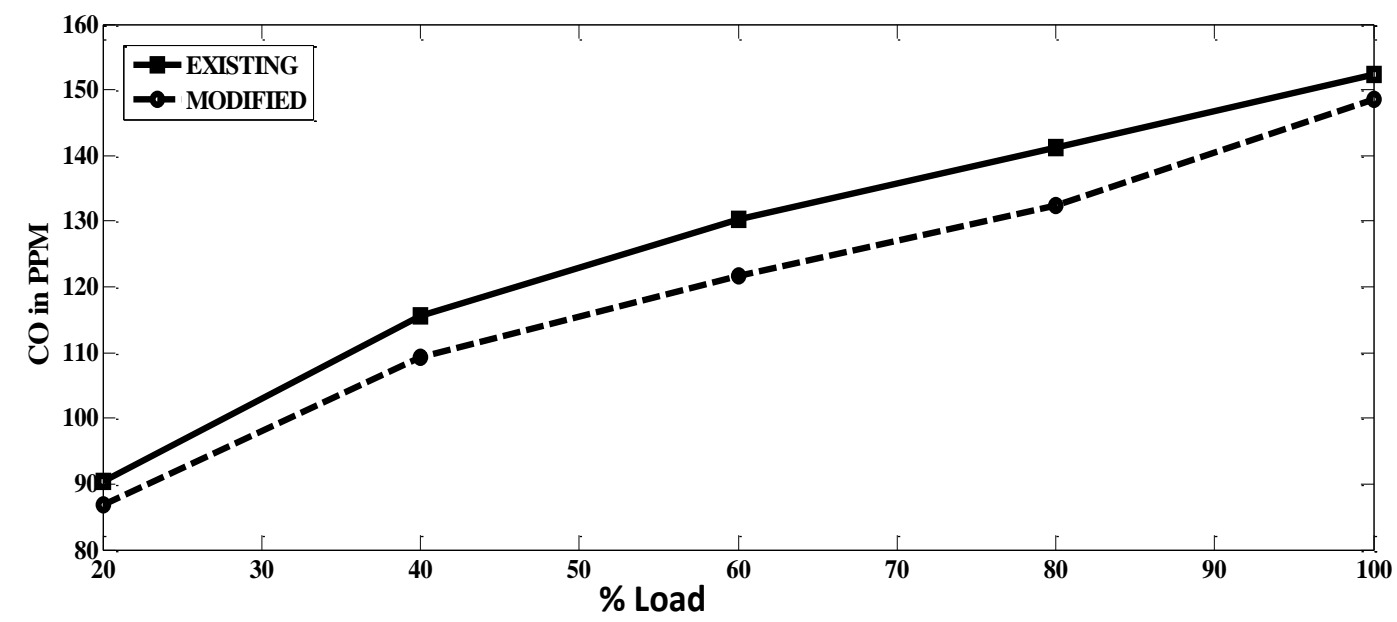

Figure 10. CO emission comparison at different loading conditions

While comparing $\mathrm{NO}_{\mathrm{X}}$ emission of both engines at their most suitable speed it was observed that $\mathrm{NO}_{\mathrm{X}}$ emission was lower for the modified engine at all loading condition. This might be because of lower speed of the existing engine because at lower engine speed the reactive gas provides a longer time for the nitric oxide to form and this results in higher nitric oxide concentration in the combustion chamber. Although in a modified engine with the higher speed the exhaust gas temperature increased, the NOX emission decreased, this might be due to increase in the volumetric efficiency and gas flow motion within the engine cylinder under higher engine speeds, leading faster mixture between fuel and air, and shorter ignition delay. The reaction time of each engine cycle is thereafter reduced so that the residence time of the gas temperature within the cylinder is shortened. This led to lower $\mathrm{NO}_{\mathrm{X}}$ emissions in the modified engine by approximately $10 \%$ at full load.

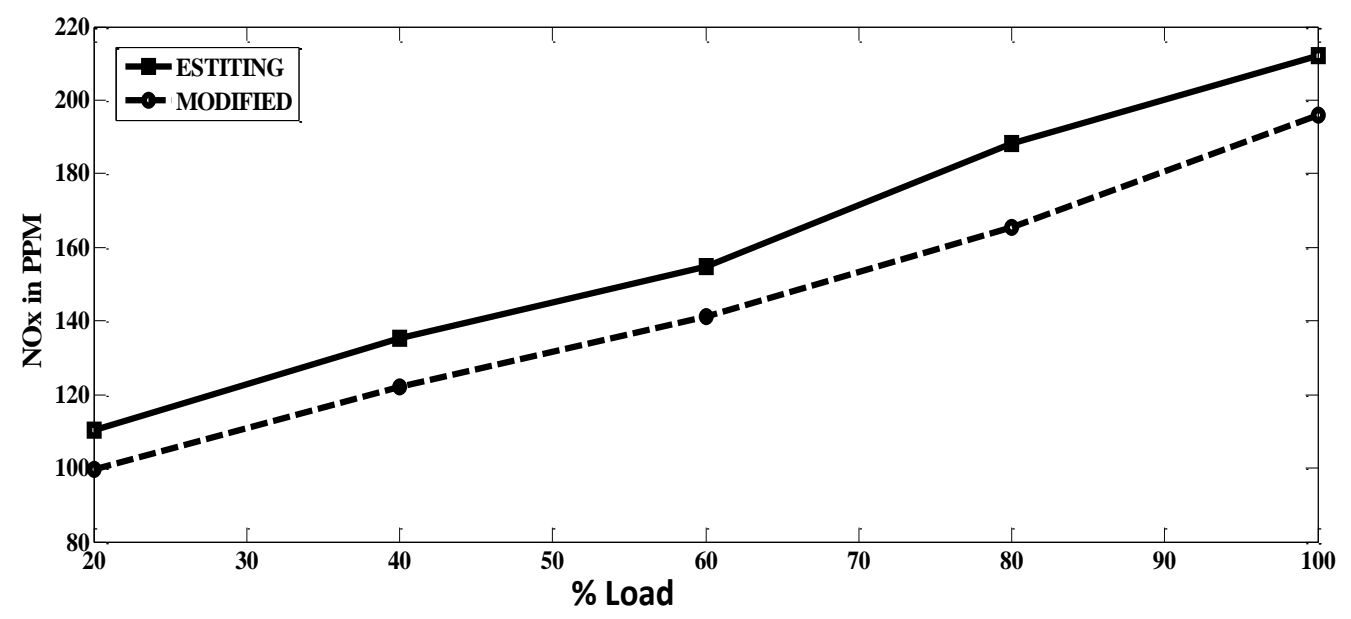

Figure $11 . \mathrm{NO}_{\mathrm{X}}$ emission comparison at different loading conditions

\section{CONCLUSION}

The present work has tried to enhance the performance and emission aspect of a single cylinder four stroke water cooled engine using weight reduction approach in the 
flywheel. The findings indicated that modified engine can be used for same rated power with reduced weight and higher speed which may lead to better convenience and mobility along with improved performance and emission aspects. The salient points are as follows.

a) By following weight reduction approach, the weight of the flywheel is reduced by $9 \mathrm{~kg}$ (i.e. from 18 to $9 \mathrm{~kg}$ ) without sacrificing the rated brake power.

b) By measuring the various performance parameters of both engines at a different speed, the highest brake thermal efficiency of $42.81 \%$ at full load for existing engine is observed at $1800 \mathrm{rpm}$ and for the modified engine, the highest brake thermal efficiency of $44.55 \%$ is observed at $2600 \mathrm{rpm}$. Considering the importance of full load efficiency for engine performance the most suitable speed for existing and modified engines are 1800 and $2600 \mathrm{rpm}$ respectively.

c) With the modified flywheel the engine operated successfully and performed better; BSFC was lower by $1.5 \%$ and BTE was better by $2 \%$ regardless of loading condition.

d) Comparing the emission aspects of both engines it can be interpreted from the graphs that modified engine gives lower emission of $\mathrm{CO}$ by $4 \%$ at full load and lower emission of $\mathrm{NO}_{\mathrm{X}}$ by $10 \%$ as compared to existing engine at their most suitable speed.

Therefore, it can be concluded that existing engine can be replaced by a modified engine with better performance and less weight but at little higher speed

\section{ACKNOWLEDGEMENT}

The authors are sincerely thankful to the management of M/s Gujarat Forgings Pvt. Ltd, Aji G.I.D.C Rajkot for allowing us to use their testing facilities. The authors are also sincerely thankful to the management of M/s Vijay Industrial Corporation, Bhaktinagar Station Plot situated at Rajkot for providing us an engine for modification.

\section{REFERENCES}

[1] Mahgoub BK, Sulaiman S, Karim ZA. Performance study of imitated syngas in a dual-fuel compression ignition diesel engine. International Journal of Automotive and Mechanical Engineering. 2015;11:2282.

[2] Adam IK, Aziz ARA, Yusup S. Determination of diesel engine performance fueled biodiesel (rubber seed/palm oil mixture) diesel blend. International Journal of Automotive and Mechanical Engineering. 2015;11:2675.

[3] Kapilan N, Ashok Babu T, Reddy R. Improvement of performance of dual fuel engine operated at part load. International Journal of Automotive and Mechanical Engineering. 2010;2:200-10.

[4] Agarwal AK. Biofuels (alcohols and biodiesel) applications as fuels for internal combustion engines. Progress in Energy and Combustion Science. 2007;33:23371.

[5] Demirbas A. Progress and recent trends in biofuels. Progress in Energy and Combustion science. 2007;33:1-18.

[6] Canakci M, Van Gerpen JH. Comparison of engine performance and emissions for petroleum diesel fuel, yellow grease biodiesel, and soybean oil biodiesel. Transactions of the ASAE. 2003;46:937. 
[7] Kalligeros S, Zannikos F, Stournas S, Lois E, Anastopoulos G, Teas C, et al. An investigation of using biodiesel/marine diesel blends on the performance of a stationary diesel engine. Biomass and Bioenergy. 2003;24:141-9.

[8] Nabi MN, Akhter MS, Shahadat MMZ. Improvement of engine emissions with conventional diesel fuel and diesel-biodiesel blends. Bioresource Technology. 2006;97:372-8.

[9] Sendzikiene E, Makareviciene V, Janulis P. Influence of fuel oxygen content on diesel engine exhaust emissions. Renewable Energy. 2006;31:2505-12.

[10] Jaichandar S, Annamalai K. Jatropha oil methyl ester as diesel engine fuel-an experimental investigation. International Journal of Automotive and Mechanical Engineering. 2016;13:3248.

[11] Tapanes NCO, Aranda DAG, de Mesquita Carneiro JW, Antunes OAC. Transesterification of Jatropha curcas oil glycerides: theoretical and experimental studies of biodiesel reaction. Fuel. 2008;87:2286-95.

[12] Dubey P, Gupta R. Study of the performance and emission characteristics for a dual fuel powered single cylinder diesel engine. International Journal of Automotive \& Mechanical Engineering. 2016;13.

[13] Azad AK, Rasul M, Giannangelo B, Islam R. Comparative study of diesel engine performance and emission with soybean and waste oil biodiesel fuels. International Journal of Automotive and Mechanical Engineering. 2015;12:2866.

[14] Raj C, Sendilvelan S. Effect of oxygenated hydrocarbon additives on exhaust emission of a diesel engine. International Journal of Automotive and Mechanical Engineering. 2010;2:144-56.

[15] Azad A, Uddin SA, Alam M. A Comprehensive study of di diesel engine performance with vegetable oil: an alternative bio-fuel source of energy. International Journal of Automotive and Mechanical Engineering (IJAME). 2012;5:576-86.

[16] Soon LB, Rus AZM, Hasan S. Continuous biodiesel production using ultrasound clamp on tubular reactor. International Journal of Automotive and Mechanical Engineering. 2013;8:1396.

[17] Yusaf T, Hamawand I, Baker P, Najafi G. The effect of methanol-diesel blended ratio on CI engine performance. International Journal of Automotive and Mechanical Engineering. 2013;8:1385.

[18] Abbaszadeh A, Ghobadian B, Najafi G, Yusaf T. An experimental investigation of the effective parameters on wet washing of biodiesel purification. International Journal of Automotive and Mechanical Engineering. 2014;9:1525.

[19] Yu L, Li-ying Z, Zi-yu W, Jian G, Fu-qiang L. Experimental investigation on the combustion characteristics of a diesel engine fueled with Jatropha curcas oil. 2011 International Conference on Materials for Renewable Energy \& Environment (ICMREE): IEEE; 2011. p. 395-9.

[20] Rostami S, Ghobadian B, Kiani MKD. Effect of the injection timing on the performance of a diesel engine using Diesel-Biodiesel blends. International Journal of Automotive and Mechanical Engineering. 2014;10:1945.

[21] Sathiyamoorthi R, Sankaranarayanan G. Fuel Injection timings of a direct injection diesel engine running on neat lemongrass oil-diesel blends. International Journal of Automotive and Mechanical Engineering. 2015;11:2348. 
[22] Raheman H, Ghadge S. Performance of compression ignition engine with mahua (Madhuca indica) biodiesel. Fuel. 2007;86:2568-73.

[23] Ramadhas A, Muraleedharan C, Jayaraj S. Performance and emission evaluation of a diesel engine fueled with methyl esters of rubber seed oil. Renewable energy. 2005;30:1789-800.

[24] Usta N. An experimental study on performance and exhaust emissions of a diesel engine fuelled with tobacco seed oil methyl ester. Energy Conversion and Management. 2005;46:2373-86.

[25] D'Andrea T, Henshaw P, Ting D-K. The addition of hydrogen to a gasolinefuelled SI engine. International Journal of Hydrogen Energy. 2004;29:1541-52.

[26] Rahman MM, Hassan MH, Kalam MA, Atabani AE, Memon LA, Rahman SA. Performance and emission analysis of Jatropha curcas and Moringa oleifera methyl ester fuel blends in a multi-cylinder diesel engine. Journal of Cleaner Production. 2014;65:304-10.

[27] Gumus M, Sayin C, Canakci M. The impact of fuel injection pressure on the exhaust emissions of a direct injection diesel engine fueled with biodiesel-diesel fuel blends. Fuel. 2012;95:486-94.

[28] Chauhan BS, Kumar N, Pal SS, Du Jun Y. Experimental studies on fumigation of ethanol in a small capacity diesel engine. Energy. 2011;36:1030-8.

[29] Abdel- Rahman A. On the emissions from internal- combustion engines: a review. International Journal of Energy Research. 1998;22:483-513.

[30] İçıngür Y, Altiparmak D. Effect of fuel cetane number and injection pressure on a DI Diesel engine performance and emissions. Energy conversion and management. 2003;44:389-97.

[31] Semin S, Bakar RA, Ismail A, Ali I. An experimental investigation of diesel engines fuel injection pressure effect on power performance and fuel consumption. International Journal of Engineering-Transactions B: Applications. 2008;22:91.

[32] Dec JE. A conceptual model of DI diesel combustion based on laser-sheet imaging. SAE Technical paper; 1997.

[33] Agarwal AK, Chaudhury V, Agarwal A, Shukla PC. Comparative study of macroscopic spray parameters and fuel atomization behaviour of SVO (jatropha), its biodiesel and blends. Thermal Science. 2013;17:217-32.

[34] Zhang G, Qiao X, Miao X, Hong J, Zheng J. Effects of highly dispersed spray nozzle on fuel injection characteristics and emissions of heavy-duty diesel engine. Fuel. 2012;102:666-73.

[35] Radha KK, Sarada SN, Rajagopal K, Nagesh E. Performance and emission characteristics of CI engine operated on vegetable oils as alternate fuels. International Journal of Automotive and Mechanical Engineering. 2011;4:41427.

[36] Agarwal AK, Srivastava DK, Dhar A, Maurya RK, Shukla PC, Singh AP. Effect of fuel injection timing and pressure on combustion, emissions and performance characteristics of a single cylinder diesel engine. Fuel. 2013;111:374-83.

[37] Nwafor O. Effect of advanced injection timing on emission characteristics of diesel engine running on natural gas. Renewable Energy. 2007;32:2361-8.

[38] Shahadat M, Nabi M, Akhter M, Tushar M. Combined Effect of EGR and Inlet Air Preheating on Engine Performance in Diesel Engine. International Energy Journal. 2008;9. 
[39] Kumar NR, Sekhar Y, Adinarayana S. Effects of compression ratio and EGR on performance, combustion and emissions of DI injection diesel engine. International Journal of Applied Science and Engineering. 2013;11:41-9.

[40] Laguitton O, Crua C, Cowell T, Heikal M, Gold M. The effect of compression ratio on exhaust emissions from a PCCI diesel engine. Energy Conversion and Management. 2007;48:2918-24.

[41] Canakci M, Ozsezen AN, Arcaklioglu E, Erdil A. Prediction of performance and exhaust emissions of a diesel engine fueled with biodiesel produced from waste frying palm oil. Expert systems with Applications. 2009;36:9268-80.

[42] Bakar RA, Lee CS. The effect of combustion parameters on the nitric oxide emission in direct injection type diesel engine. Journal of Mechanical Science and Technology. 1997;11:672-80.

[43] Jindal S. Effect of engine parameters on NOx emissions with Jatropha biodiesel as fuel. International Journal of Energy and Environment. 2010;1:343-50.

[44] Sayin C, Kilicaslan I, Canakci M, Ozsezen N. An experimental study of the effect of octane number higher than engine requirement on the engine performance and emissions. Applied Thermal Engineering. 2005;25:1315-24. 